Revised manuscript submitted to: Journal of Power Sources

Date: July 25, 2014

\title{
Pt-modified Molybdenum Carbide for the Hydrogen Evolution Reaction: From Model Surfaces to Powder Electrocatalysts
}

Thomas G. Kelly ${ }^{\mathrm{a}}$, Kevin X. Lee ${ }^{\mathrm{b}}$ and Jingguang G. Chen ${ }^{\mathrm{b}_{*}}$

${ }^{a}$ Department of Chemical and Biomolecular Engineering, University of Delaware, Newark, DE 19716

${ }^{\mathrm{b}}$ Department of Chemical Engineering, Columbia University, New York, NY 10027

* Corresponding author: jgchen@ columbia.edu 


\begin{abstract}
This work explores the opportunity to substantially reduce the cost of hydrogen evolution reaction (HER) electrocatalysts by supporting one monolayer (ML) of platinum $(\mathrm{Pt})$ on lowcost molybdenum carbide $\left(\mathrm{Mo}_{2} \mathrm{C}\right)$ substrate. These efforts were primarily directed towards scaling a thin-film catalyst to high surface area particles. Electrochemical experiments investigated single-phase $\mathrm{Mo}_{2} \mathrm{C}$ thin films modified by different coverages of $\mathrm{Pt}$ for the HER. The ML Pt- $\mathrm{Mo}_{2} \mathrm{C}$ thin film showed Pt-like HER activity while displaying excellent stability under HER conditions. The promising results on thin films were then extended to more practical powder catalysts. Samples of various $\mathrm{Pt}$ loadings on $\mathrm{Mo}_{2} \mathrm{C}$ powders were synthesized using the co-impregnation method and were evaluated for HER activity. The ability to successfully link electrochemical activity on thin films and powder catalysts was thus demonstrated.
\end{abstract}




\section{Introduction}

Low- temperature water electrolyzers show promise as sources of hydrogen. For example, a proton exchange membrane (PEM) electrolyzer can produce $\mathrm{H}_{2}$ at high levels of pressure and purity. As compared to traditional alkaline electrolyzers, a PEM cell does not contain a caustic liquid electrolyte that is difficult to transport. However, due to the acidic environment and need for high current density, PEMs utilize scarce and expensive precious metals such as platinum $(\mathrm{Pt})$. With the demand for hydrogen and the extensive development of fuel cells and PEM electrolyzers, the global reserves of Pt are gradually decreasing. Therefore, it is necessary to search for alternative electrocatalysts that substantially decrease or eliminate altogether the amount of $\mathrm{Pt}$, without losing the performance of conventional $\mathrm{Pt}$ electrocatalysts.

One method of minimizing Pt loading is to use metal carbides as support materials for one monolayer (ML) of Pt. Recent findings have shown that Pt monolayer supported on tungsten carbide (Pt/WC or $\mathrm{W}_{2} \mathrm{C}$ ) showed HER activity almost identical to that of Pt bulk foil [1]. However, the synthesis of WC requires extremely high temperatures that could promote the sintering of small WC particles into larger ones, decreasing the surface area [2]. Another metal carbide, molybdenum carbide $\left(\mathrm{Mo}_{2} \mathrm{C}\right)$, can be synthesized at lower temperatures and thus has a higher surface area than WC. Recently, porous $\mathrm{Mo}_{2} \mathrm{C}$ catalysts were synthesized with a surface area of $94 \mathrm{~m}^{2} \mathrm{~g}^{-1}$ and were active for the hydrodeoxygenation of C3 oxygenates to alkenes [3]. Additionally, $\mathrm{Mo}_{2} \mathrm{C}$ has shown to be a promising support material in both gasphase and electrochemical systems [4,5]. Moreover, similar to $\mathrm{WC}, \mathrm{Mo}_{2} \mathrm{C}$ is electrochemically stable at HER conditions in acidic solution [6,7]. Pt-modified Mo2C has previously been used as a catalyst for cellulose conversion to polyols [8] and the water-gas shift reaction [9]. Additionally, $\mathrm{Pt} / \mathrm{Mo} 2 \mathrm{C}$ was studied as an electrocatalyst for the oxygen 
reduction reaction [10]. This prior work makes $\mathrm{Mo}_{2} \mathrm{C}$ a promising material to support ML Pt as low-cost HER electrocatalysts.

There are two primary objectives in the current study. First, we seek to explore Ptmodified $\mathrm{Mo}_{2} \mathrm{C}$ HER catalysts by studying the deposition of sub-ML to ML amounts of Pt loadings on single-phase $\mathrm{Mo}_{2} \mathrm{C}$ thin films. Previously, HER activity was shown to be correlated to the hydrogen binding energy (HBE) in both monometallic and bimetallic alloys $[11,12]$. Materials such as the Pt-group metals have intermediate HBE values, which result in high HER activity. In the current study, electrochemical experiments were conducted to evaluate the activity and stability of single-phase $\mathrm{Mo}_{2} \mathrm{C}$ and $\mathrm{ML} \mathrm{Pt} / \mathrm{Mo}_{2} \mathrm{C}$ films. Polycrystalline $\mathrm{Mo}_{2} \mathrm{C}$ foils were synthesized using temperature programmed reaction with methane and hydrogen. Multiple coverages of Pt were deposited on the foils by physical vapor deposition (PVD). X-ray photoelectron spectroscopy (XPS) was used to verify the carbide stoichiometry and overlayer coverage of Pt. Electrochemical measurements such as linear sweep voltammetry (LSV) and chronopotentiometry (CP) were utilized to assess the activity and stability of the $\mathrm{Pt} / \mathrm{Mo}_{2} \mathrm{C}$ electrocatalysts. Finally, XPS characterization was compared before and after electrochemical experiments to determine catalyst stability.

The second objective of this study is to scale up the ML Pt-Mo $\mathrm{M}_{2} \mathrm{C}$ thin film system to more commercially viable powder electrocatalysts. The motivation for synthesizing catalysts in powder form is driven by their high surface area and ease of impregnation on carbon paper. HER measurements were conducted to compare samples of $\mathrm{Mo}_{2} \mathrm{C}$ with different loadings of Pt with $10 \mathrm{wt} \% \mathrm{Pt}$ supported on high surface area carbon (Pt/C) to determine whether Pt-Mo $\mathrm{M}_{2} \mathrm{C}$ powder showed good catalytic activity for HER in acidic environment as predicted from the results on $\mathrm{ML} \mathrm{Pt}-\mathrm{Mo}_{2} \mathrm{C}$ thin films.

\section{Methods}




\subsection{Synthesis and Characterization of Pt-modified $\mathrm{Mo}_{2} \mathrm{C}$ Thin Films}

Polycrystalline Mo foils (Alfa Aesar, 99.95\%, $0.1 \mathrm{~mm}$ ) were rinsed with deionized (DI) water and methanol, and dipped in a $0.3 \mathrm{M} \mathrm{NaOH}$ solution for one minute (Fisher Scientific, $99.5 \%$ ), which has been shown to remove surface oxides $[7,13]$. The treated foils were placed within a Lindberg furnace (model 55035) to synthesize $\mathrm{Mo}_{2} \mathrm{C}$ by direct carburization with methane $\left(\mathrm{CH}_{4}\right)$ and hydrogen $\left(\mathrm{H}_{2}\right)$ using flow rates of 33 and $122 \mathrm{sccm}$ (molar ratio 21\% and 79\%), respectively. The high temperature synthesis step for $\mathrm{Mo}_{2} \mathrm{C}$ was carried out at $850{ }^{\circ} \mathrm{C}$. At the end of the synthesis procedure, $\mathrm{H}_{2}$ was fed for two hours to remove excess surface carbon, as previously verified using XPS [14]. The samples were then exposed to a mixture of $1 \% \mathrm{O}_{2}$ in $99 \% \mathrm{~N}_{2}$ for three hours at room temperature to passivate the surface defects to prevent severe oxidation upon exposing $\mathrm{Mo}_{2} \mathrm{C}$ to atmospheric oxygen.

The $\mathrm{Mo}_{2} \mathrm{C}$ foils were rinsed with DI water, methanol, and dipped in a $0.3 \mathrm{M} \mathrm{NaOH}$ solution for one minute. Within ten minutes of ambient exposure, the samples were transferred into a PVD chamber with a base pressure of $1 \times 10^{-8}$ Torr. A $0.5 \mathrm{~mm}$ diameter tungsten filament with a $0.2 \mathrm{~mm}$ diameter Pt wire (Alfa Aesar, 99.9\%) coiled around the filament was resistively heated to evaporate $\mathrm{Pt}$ on the $\mathrm{Mo}_{2} \mathrm{C}$ substrate. This thermal evaporation method has been commonly employed in the preparation of ML metal over carbide surfaces [15].

Once the $\mathrm{Pt} / \mathrm{Mo}_{2} \mathrm{C}$ samples were synthesized, they were transferred into a Phi 5600 XPS chamber within ten minutes of ambient exposure. The XPS was calibrated using the reported binding energies of $\mathrm{Au}, \mathrm{Ag}$, and $\mathrm{Cu}$ reference thin films [16]. The Pt overlayer coverage was calculated using the inelastic mean free path (IMFP) values provided in Cumpson and Seah [17]. Further details can be found in previous publications $[1,18]$. After the electrochemical experiments, the samples were transferred into the XPS chamber within ten minutes of ambient exposure for further characterization. 


\subsection{Preparation and Characterization of $\mathrm{Pt} / \mathrm{Mo}_{2} \mathrm{C}$ Powders}

For each experiment, $20 \mu \mathrm{L}$ of ink sample was dropped onto the center of a glassy carbon substrate. The ink was an aqueous suspension of $\sim 2.6 \mathrm{mg}$ of catalyst / $\mathrm{mL}$ of solvent produced by ultrasonically dispersing a metal loading of $0.0025,0.005,0.01,0.02,0.04,0.06$, 0.08, 0.1 (g of catalyst / $\mathrm{g}$ of support) for 1 hour in deionized water. The catalyst was prepared by co-impregnating Pt metals on $\mathrm{Mo}_{2} \mathrm{C}$ immersed in an oil bath at a temperature of $\sim 65^{\circ} \mathrm{C}$ until all of the water was evaporated, followed by a 2 hour calcination process at 290 ${ }^{\circ} \mathrm{C}$ in order to remove volatile fractions such as $\mathrm{NO}_{3}{ }^{-}$from the respective precursors. Once the metal was uniformly dispersed in water solvent, the ink was dropped onto the glassy carbon electrode by forming a ring of droplets on the outside edge of the disk, and then filling the middle with the remainder of the ink. This procedure was calculated to yield a catalyst loading of $10 \mu \mathrm{g} \mathrm{cm}^{-2}$ for a standard electrode geometric surface area of $0.196 \mathrm{~cm}^{2}$. After the ink dried on the electrode, a single drop of Nafion was pipetted onto the catalyst and allowed to dry for a stronger binding between the catalyst and the surface of the electrode. Inductively coupled plasma (ICP) was used to test for dissolution of $\mathrm{Pt} / \mathrm{Mo}_{2} \mathrm{C}$ powders from the disk into the electrolyte solution.

\subsection{Electrochemical Measurements}

Electrochemical measurements were performed using a three-electrode glass cell containing 0.5 M sulfuric acid solution $\left(\mathrm{H}_{2} \mathrm{SO}_{4}\right.$, Fisher Scientific, 96.9\%) using a Princeton Applied Research Versastat 4 potentiostat. The solution was prepared with DI water purified to a resistivity above $17 \mathrm{M} \Omega-\mathrm{cm}$ by a Barnstead NAN-Opure filtration system. Pt gauze (Alfa Aesar, 99.9\%) was used as the counter electrode. Twenty-five cyclic voltammetry (CV) scans between 0 and $0.4 \mathrm{~V}$ vs NHE were used to clean and condition the $\mathrm{Pt} / \mathrm{Mo}_{2} \mathrm{C}$ electrode surfaces, and scans in the range of 0-1.4 V were used to clean the Pt reference wire. LSV measurements from +0.1 to $-0.4 \mathrm{~V}$ vs $\mathrm{NHE}$ at a sweep rate of $2 \mathrm{mV} / \mathrm{s}$ were used to measure 
the HER activity by generating Tafel plots. LSV measurements were performed in Ar-purged solution with a saturated calomel electrode (SCE) used as the reference.

Chronopotentiometry (CP) was used to measure the electrochemical stability of the samples over two hours of HER operation; alternating periods without current for five minutes and $10.0 \mathrm{~mA} \mathrm{~cm}^{-2}$ for twenty-five minutes were used to simulate the intermittent operation typical of an electrolysis device. A Pt wire with $\mathrm{H}_{2}$ bubbled through the solution to maintain saturation was used as an internal reference electrode for the $\mathrm{CP}$ experiments.

\section{Results and Discussion}

\subsection{Structure and Activity of Thin Films}

The $\mathrm{Pt} / \mathrm{Mo}_{2} \mathrm{C}$ thin film system was first evaluated to determine its growth mechanism by using XPS. Figure 1 shows the Pt coverage as a function of deposition time on a thin $\mathrm{Mo}_{2} \mathrm{C}$ film. The increase in Pt film thickness was linear with respect to deposition time, suggesting that $\mathrm{Pt}$ growth was layer-by-layer on $\mathrm{Mo}_{2} \mathrm{C}$. The layer-by-layer mechanism agrees with that seen previously for Pt on a WC substrate [1].

The Pt-modified $\mathrm{Mo}_{2} \mathrm{C}$ thin films, with different Pt coverages, were evaluated for HER activity. Figure 2 shows a CV performed in Ar-saturated $0.5 \mathrm{M} \mathrm{H}_{2} \mathrm{SO}_{4}$ on $1.45 \mathrm{ML}$ $\mathrm{Pt} / \mathrm{Mo}_{2} \mathrm{C}$. At this Pt coverage, no peaks due to hydrogen adsorption and desorption are visible. Additionally, the surface begins to oxidize at $600 \mathrm{mV}$ vs NHE. For this reason, we only performed cleaning scans to $400 \mathrm{mV}$. Figure 3 shows the LSV measurements performed on $\mathrm{Mo}_{2} \mathrm{C}, \mathrm{Pt}$, and Pt-modified $\mathrm{Mo}_{2} \mathrm{C}$. As expected, the current density shown on unmodified $\mathrm{Mo}_{2} \mathrm{C}$ was extremely low, but modification with $0.5 \mathrm{ML}$ Pt produced a substantial increase in current density. Tafel plots generated from the LSV data also show a substantial difference between $\mathrm{Mo}_{2} \mathrm{C}$ and Pt-modified $\mathrm{Mo}_{2} \mathrm{C}$. As shown in Figure 4, the activity of Pt overlayers above $0.5 \mathrm{ML}$ was indistinguishable from Pt foil at low current 
densities. The reversible potential for hydrogen evolution was calculated by using the Nernst equation with $\mathrm{pH}$ calculated from the acid concentration. Also, the overpotential was corrected by performing a CV of Pt foil from 0 to $1.4 \mathrm{~V}$ vs NHE. The peak locations for hydrogen desorption in the $\mathrm{CV}$ were shifted by $-0.05 \mathrm{~V}$ with respect to the literature values on polycrystalline Pt [19]. Adding the Nernst value to this correction resulted in the reversible potential of $-0.068 \mathrm{~V}$ with respect to the measured overpotential, as indicated on Figure 4. The current on each surface at this potential was extracted and plotted versus Pt coverage in Figure 5. For bare $\mathrm{Mo}_{2} \mathrm{C}$, the $\log$ of the exchange current density was -6.1 , about three orders of magnitude lower than $\mathrm{Pt}$ foil. Modification of $\mathrm{Mo}_{2} \mathrm{C}$ with even $0.5 \mathrm{ML} \mathrm{Pt}$ resulted in substantial enhancement of HER activity. The activity observed for the HER on the $\mathrm{Pt} / \mathrm{Mo}_{2} \mathrm{C}$ system agrees with that observed previously for $\mathrm{Pt} / \mathrm{WC}$, where a monolayer of Pt effectively behaved like bulk Pt [1].

Long-term stability tests also demonstrated the effectiveness of Pt-modified $\mathrm{Mo}_{2} \mathrm{C}$ as HER catalysts. During the experiment, two different segments were studied: first, a 5-minute period with no current, then a 25 -minute period with a reducing current of $10 \mathrm{~mA} \mathrm{~cm}{ }^{-2}$. The sequence was repeated over a two hour period. The results from a 2-hour chronopotentiometry experiment in $\mathrm{H}_{2}$-saturated $0.5 \mathrm{M} \mathrm{H}_{2} \mathrm{SO}_{4}$ are shown in Figure 6. For bulk $\mathrm{Mo}_{2} \mathrm{C}$, the open-circuit potential was about $+500 \mathrm{mV}$ vs NHE, indicating surface oxidation and corrosion. During hydrogen evolution, the overpotential on $\mathrm{Mo}_{2} \mathrm{C}$ was between 300-350 mV. Upon Pt modification, the open-circuit potential was close to the NHE. Additionally, the operating overpotential drastically decreased. At a coverage of 1.5 ML, the operating overpotential was about $70 \mathrm{mV}$, about the same as that of Pt foil (data not shown). The overpotential did not increase over time for this sample, indicating the stability of the Pt overlayer on $\mathrm{Mo}_{2} \mathrm{C}$. 
Finally, XPS characterization of Pt-modified $\mathrm{Mo}_{2} \mathrm{C}$ thin films demonstrated its electrochemical stability. Figure 7(a) shows the XPS spectra for $1.5 \mathrm{ML} \mathrm{Pt} / \mathrm{Mo}_{2} \mathrm{C}$, before and after electrochemical experiments. As expected from the stable chronopotentiometry results, the Pt $4 \mathrm{f}$ signal did not decrease noticeably with respect to the Mo 3d signal after experiments. This is reflected in Figure 7(b), which shows the Pt $4 \mathrm{f} / \mathrm{Mo} 3 \mathrm{~d}$ ratio for 1.1 and 1.5 ML Pt/Mo $2 \mathrm{C}$ thin films. For the lower-coverage sample, the intensity ratio did decrease slightly. This may be due to $\mathrm{Pt}$ aggregation or dissolution, or dissolution of $\mathrm{MoO}_{\mathrm{x}}$ species formed during the cleaning CV. The 1.5 ML sample actually showed a slight increase in the $\mathrm{Pt} 4 \mathrm{f} / \mathrm{Mo} 3 \mathrm{~d}$ ratio. The experimental results indicate little Pt aggregation or dissolution.

\subsection{Extension to Powder Catalysts}

Despite the promising results on thin films, further research is needed before metalmodified carbides can be considered viable HER electrocatalysts. Powder catalysts with various loadings of $\mathrm{Pt}$ on $\mathrm{Mo}_{2} \mathrm{C}$ were synthesized and tested for HER activity. The similarity of $\mathrm{Pt} / \mathrm{Mo}_{2} \mathrm{C}$ powders to $\mathrm{Pt} / \mathrm{C}$ can be seen in the $\mathrm{CV}$ plots of Figure 8 . Unmodified $\mathrm{Mo}_{2} \mathrm{C}$ shows very broad, undefined peaks for the adsorption and desorption of $\mathrm{H}^{+}$. Upon modifying the $\mathrm{Mo}_{2} \mathrm{C}$ powders with $0.25 \mathrm{wt} \% \mathrm{Pt}$, a distinct peak at $190 \mathrm{mV}$ vs NHE can be observed. At higher loadings of $2 \mathrm{wt} \%$ and above, these peaks are well-defined similar to the Pt/C standard. LSV measurements also showed a similar trend. The log of the exchange current densities were calculated from the Tafel parameters and are plotted against $\mathrm{Pt} w \mathrm{t} \%$ loadings on $\mathrm{Mo}_{2} \mathrm{C}$, as shown in Figure 9. The exchange current density of the $10 \mathrm{wt} \% \mathrm{Pt} / \mathrm{C}$ catalyst is represented by the straight line. For unmodified $\mathrm{Mo}_{2} \mathrm{C}$ powders, the log of the exchange current density was -4.31 , about two orders of magnitude lower than $\mathrm{Pt} / \mathrm{C}$. Increasing the $\mathrm{Pt}$ wt\% resulted in the $\mathrm{Pt} / \mathrm{Mo}_{2} \mathrm{C}$ current density being close to the $\mathrm{Pt} / \mathrm{C}$ value, in agreement with the results on thin films. As little as $0.25 \mathrm{wt} \% \mathrm{Pt}$ on $\mathrm{Mo}_{2} \mathrm{C}$ was capable of increasing the HER 
activity significantly from unmodified $\mathrm{Mo}_{2} \mathrm{C}$. At $2 \mathrm{wt} \%$ of Pt the HER activity became comparable to that of the $\mathrm{Pt} / \mathrm{C}$ catalyst.

Because catalysts in powder form, with the addition of Nafion, prevent the use of XPS after electrochemical experiments, an inductively coupled plasma (ICP) with Mo and Pt ICP standards in nitric acid was used to determine the possible dissolution of the $\mathrm{Pt} / \mathrm{Mo}_{2} \mathrm{C}$ catalyst. Measurements from ICP are shown in Table 1. Results indicated that electrolyte solutions for $\mathrm{Pt} / \mathrm{Mo}_{2} \mathrm{C}$ samples show the presence of Mo in the range of 30-40 ppb. Furthermore, ICP measurements showed only trace amounts of Pt. This analysis altogether suggests that while there was a small amount of catalyst present in the solution, dissolution of the sample was insignificant.

\section{Conclusions}

The modification of $\mathrm{Pt}$ on $\mathrm{Mo}_{2} \mathrm{C}$ for hydrogen evolution catalysts was explored to better understand the scaling from thin film model surfaces to higher surface area particles. First, $\mathrm{Pt} / \mathrm{Mo}_{2} \mathrm{C}$ thin films were found to be electrochemically active for hydrogen evolution and stable after two hours of HER. In this regard, the results for $\mathrm{Pt}$ on $\mathrm{Mo}_{2} \mathrm{C}$ agreed with earlier experiments for Pt on WC.

Then, $\mathrm{Pt} / \mathrm{Mo}_{2} \mathrm{C}$ core-shell particles were synthesized using a co-impregnation method to deposit various $\mathrm{Pt}$ wt $\%$ on $\mathrm{Mo}_{2} \mathrm{C}$ powder substrates to compare the $\mathrm{ML} \mathrm{Pt} / \mathrm{Mo}_{2} \mathrm{C}$ thin film system to more commercially viable electrocatalysts. In terms of reducing the Pt loading while maintaining Pt bulk-like performance, the $\mathrm{Pt} / \mathrm{Mo}_{2} \mathrm{C}$ core-shell powder catalysts produced HER results that are quite similar to that of the $\mathrm{ML} \mathrm{Pt} / \mathrm{Mo}_{2} \mathrm{C}$ thin films. Both thin film and powder catalysts showed substantial enhancement in HER activity when Pt was deposited onto $\mathrm{Mo}_{2} \mathrm{C}$ substrates. These combined results demonstrate the ability to use a model structure for verification, and then synthesize a practically useful electrocatalyst. 
Further work should involve optimization of synthetic methods to better develop a new class of electrocatalysts.

\section{Acknowledgments}

The authors acknowledge financial support from the US Department of Energy, Office of Basic Energy Sciences (Grant \#DE-FG02-13ER16381).

\section{List of Figures}

Figure 1: Pt coverage as a function of deposition time on $\mathrm{Mo}_{2} \mathrm{C}$, as measured by XPS.

Figure 2: Cyclic voltammogram of 1.45 ML Pt/Mo ${ }_{2} \mathrm{C}$, performed in Ar-saturated $0.5 \mathrm{M}$ $\mathrm{H}_{2} \mathrm{SO}_{4}$ at a sweep rate of $50 \mathrm{mV} / \mathrm{s}$.

Figure 3: Linear sweep voltammograms of $\mathrm{Mo}_{2} \mathrm{C}$ and Pt-modified $\mathrm{Mo}_{2} \mathrm{C}$ in Ar-saturated 0.5 $\mathrm{M} \mathrm{H}_{2} \mathrm{SO}_{4}$, recorded at a sweep rate of $2 \mathrm{mV} / \mathrm{s}$. Pt foil is provided for comparison.

Figure 4: Tafel plots for $\mathrm{Mo}_{2} \mathrm{C}$ and Pt-modified $\mathrm{Mo}_{2} \mathrm{C}$ from LSV data. The reversible potential for hydrogen evolution is indicated as $\mathrm{E}_{0}$.

Figure 5: Logarithm of the exchange current density for hydrogen evolution on $\mathrm{Pt} / \mathrm{Mo}_{2} \mathrm{C}$ foils.

Figure 6: Chronopotentiometry measurements on $\mathrm{Mo}_{2} \mathrm{C}$ and $\mathrm{Pt}$-modified $\mathrm{Mo}_{2} \mathrm{C}$ in $\mathrm{H}_{2}-$ saturated $0.5 \mathrm{M} \mathrm{H}_{2} \mathrm{SO}_{4}$. Current alternated between no current and $-10 \mathrm{~mA} \mathrm{~cm}$.

Figure 7: (a) XPS spectra of Mo3d and Pt4f regions on 1.5 ML Pt/Mo $\mathrm{Mo}_{2} \mathrm{C}$ before and after electrochemistry and (b) Pt4f / Mo3d intensity ratio before and after electrochemistry for $\mathrm{Pt} / \mathrm{Mo}_{2} \mathrm{C}$ samples.

Figure 8: Cyclic voltammetry measurements on (a) $\mathrm{Mo}_{2} \mathrm{C}$ powders, (b,c) Pt-modified $\mathrm{Mo}_{2} \mathrm{C}$, and (d) $10 \mathrm{wt} \% \mathrm{Pt} / \mathrm{C}$.

Figure 9: Logarithm of the exchange current density for hydrogen evolution on $\mathrm{Pt} / \mathrm{Mo}_{2} \mathrm{C}$ powders.

\section{List of Tables}

Table 1: Inductively-coupled plasma measurements of electrolyte solution following electrochemical experiments with $\mathrm{Pt} / \mathrm{Mo}_{2} \mathrm{C}$ powders. Concentration given in 
parts-per-billion. Numbers following element names indicate detection wavelength, and RSD represents relative standard deviation of the samples.

\section{References}


[1] D.V. Esposito, S.T. Hunt, Y.C. Kimmel, J.G. Chen, J. Am. Chem. Soc. 134 (2012) 30253033.

[2] R. Barthos, A. Széchenyi, Á. Koós, F. Solymosi, Appl. Catal. A-Gen. 327 (2007) 95-105.

[3] H. Ren, W. Yu, M. Salciccioli, Y. Chen, Y. Huang, K. Xiong, D.G. Vlachos, J.G. Chen, ChemSusChem 6 (2013) 798-801.

[4] H.H. Hwu, J.G. Chen, Chem. Rev. 105 (2005) 185-212.

[5] R. Barthos, F. Solymosi, J. Catal. 249 (2007) 289-299.

[6] E.C. Weigert, D.V. Esposito, J.G. Chen, J. Power Sources 193 (2009) 501-506.

[7] M.C. Weidman, D.V. Esposito, Y.-C. Hsu, J.G. Chen, J. Power Sources 202 (2012) 1117.

[8] J. Lee, L. Liu, Y. Liu, M. Li, Y. Zhu, H. Liu, Y. Kou, J. Zhang, Y. Han, D. Ma, Energy Environ. Sci. 7 (2013) 393-398.

[9] N.M. Schweitzer, J.A. Schaidle, O.K. Ezekoye, X. Pan, S. Linic, L.T. Thompson, J. Am. Chem. Soc. 133 (2011) 2378-2381.

[10] M. Pan, C. Li, L. Ding, J. Zhang, D. Su, W. Li, C. Liang, Ind. Eng. Chem. Res. 49 (2010) 4169-4174.

[11] J.K. Norskov, T. Bligaard, A. Logadottir, J.R. Kitchin, J.G. Chen, S. Pandelov, J. Electrochem. Soc. 152 (2005) J23-J26.

[12] J. Greeley, T.F. Jaramillo, J. Bonde, I.B. Chorkendorff, J.K. Norskov, Nat. Mater. 5 (2006) 909-913.

[13] M.C. Weidman, D.V. Esposito, I.J. Hsu, J.G. Chen, J. Electrochem. Soc. 157 (2010) F179-F188.

[14] Y.C. Kimmel, D.V. Esposito, R.W. Birkmire, J.G. Chen, Int. J. Hydrogen Energ. 37 (2012) 3019-3024.

[15] T.G. Kelly and J.G. Chen, Chem. Soc. Rev. 41 (2012) 8021-8034. 
[16] J.F. Moulder, W.F. Stickle, P.E. Sobol, K.D. Bomben, Handbook of X-ray Photoelectron Spectroscopy, Physical Electronics, Inc., Eden Prairie, MN, 1995.

[17] P.J. Cumpson, M.P. Seah, Surf. Interface Anal. 25 (1997) 430-446.

[18] D.V. Esposito, S.T. Hunt, A.L. Stottlemyer, K.D. Dobson, B.E. McCandless, R.W. Birkmire, J.G. Chen, Angew. Chem. Int. Edit. 49 (2010) 9859-9862.

[19] J. Clavilier, J.M. Orts, R. Gómez, J.M. Feliu, A. Aldaz, J. Electroanal. Chem. 404 (1996) 281-289. 


\begin{tabular}{|l|l|l|l|l|}
\hline Sample & Mo 202.030 & Mo 281.615 & Pt 214.425 & Pt 265.945 \\
\hline 1 & 50 & 40 & 10 & 10 \\
\hline 2 & 40 & 30 & 10 & 10 \\
\hline 3 & 40 & 30 & 0 & 10 \\
\hline 4 & 40 & 30 & 10 & 10 \\
\hline RSD (\%) & 17.54 & 14.47 & 10.95 & 17.29 \\
\hline
\end{tabular}




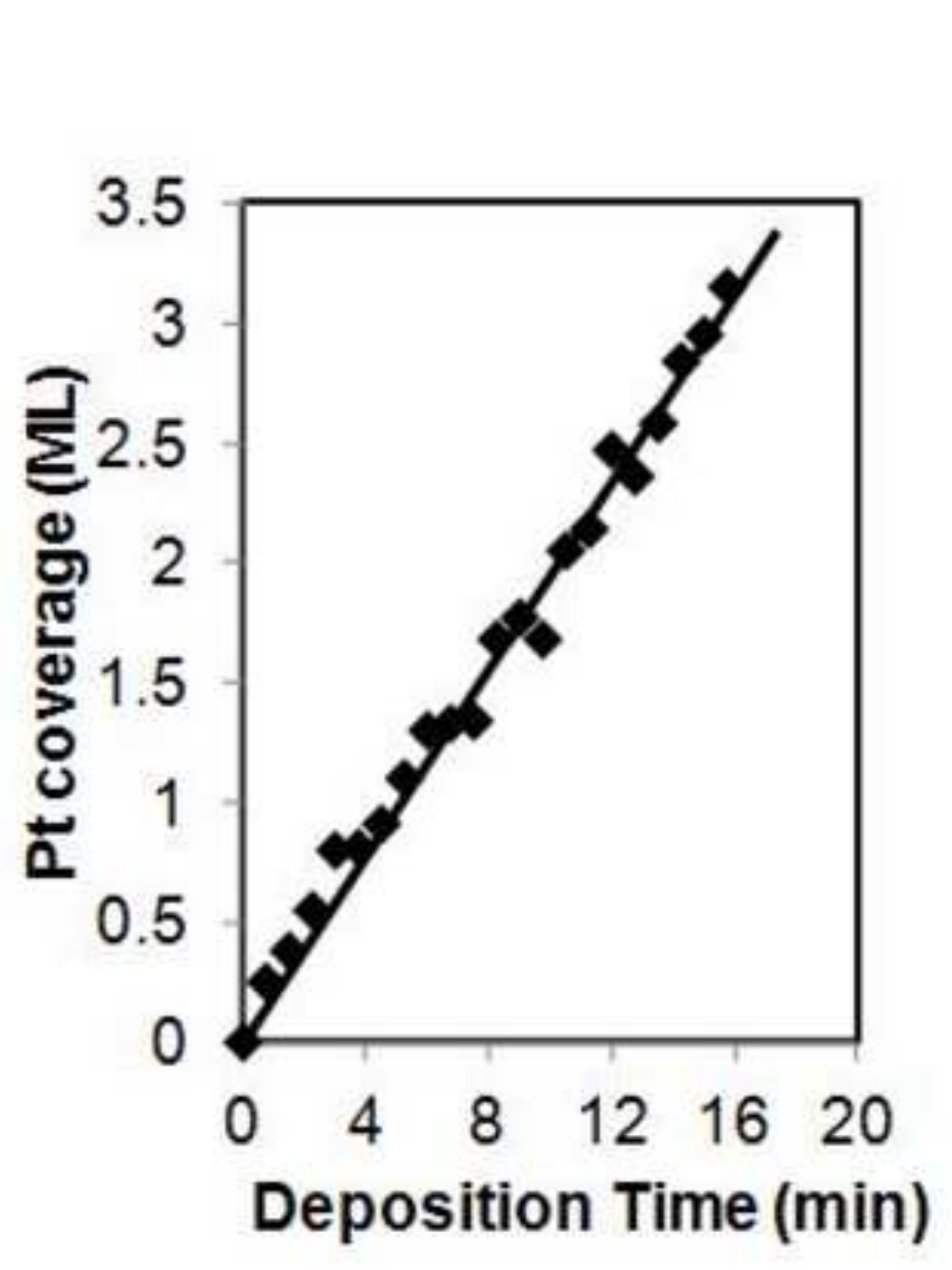




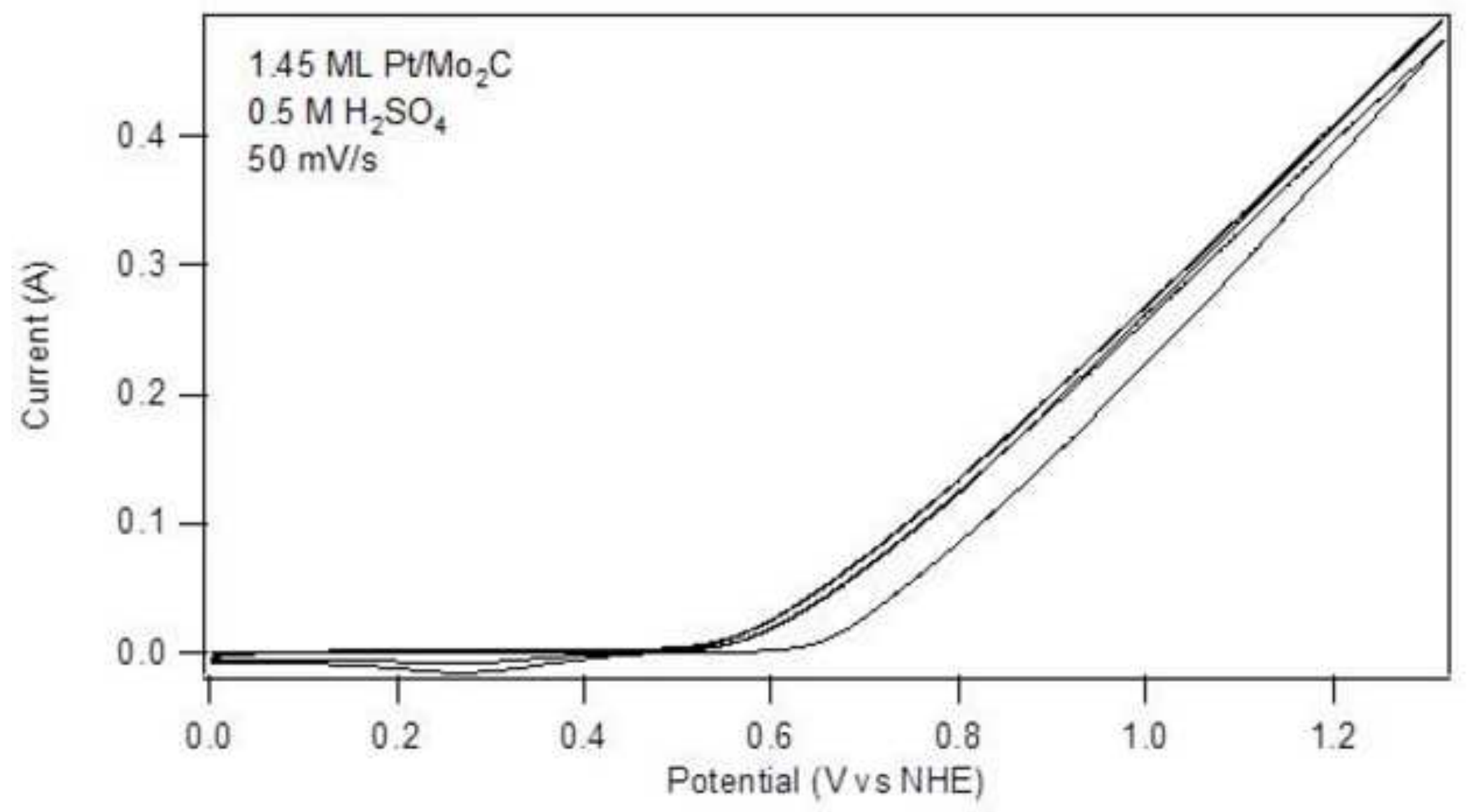




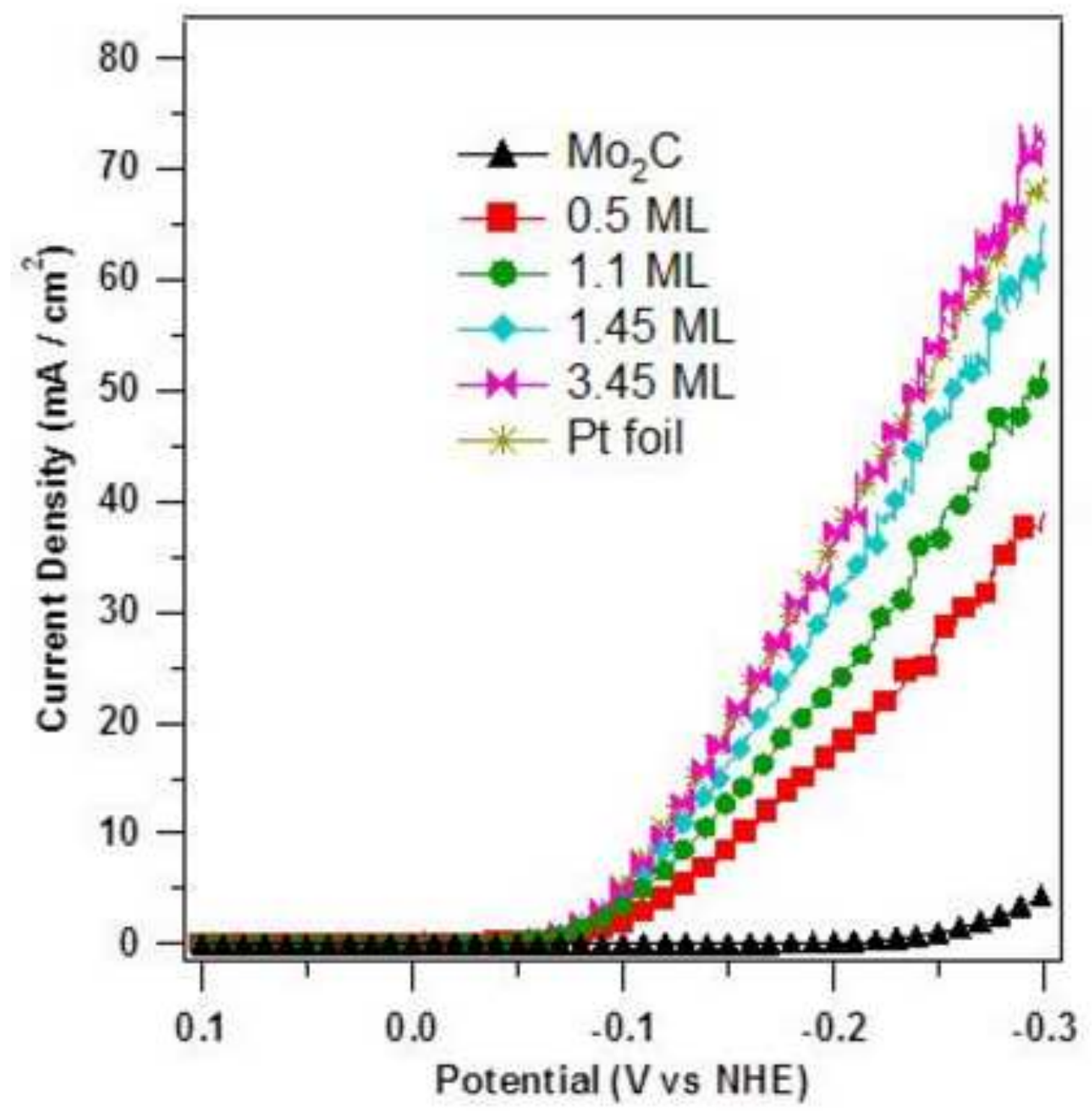




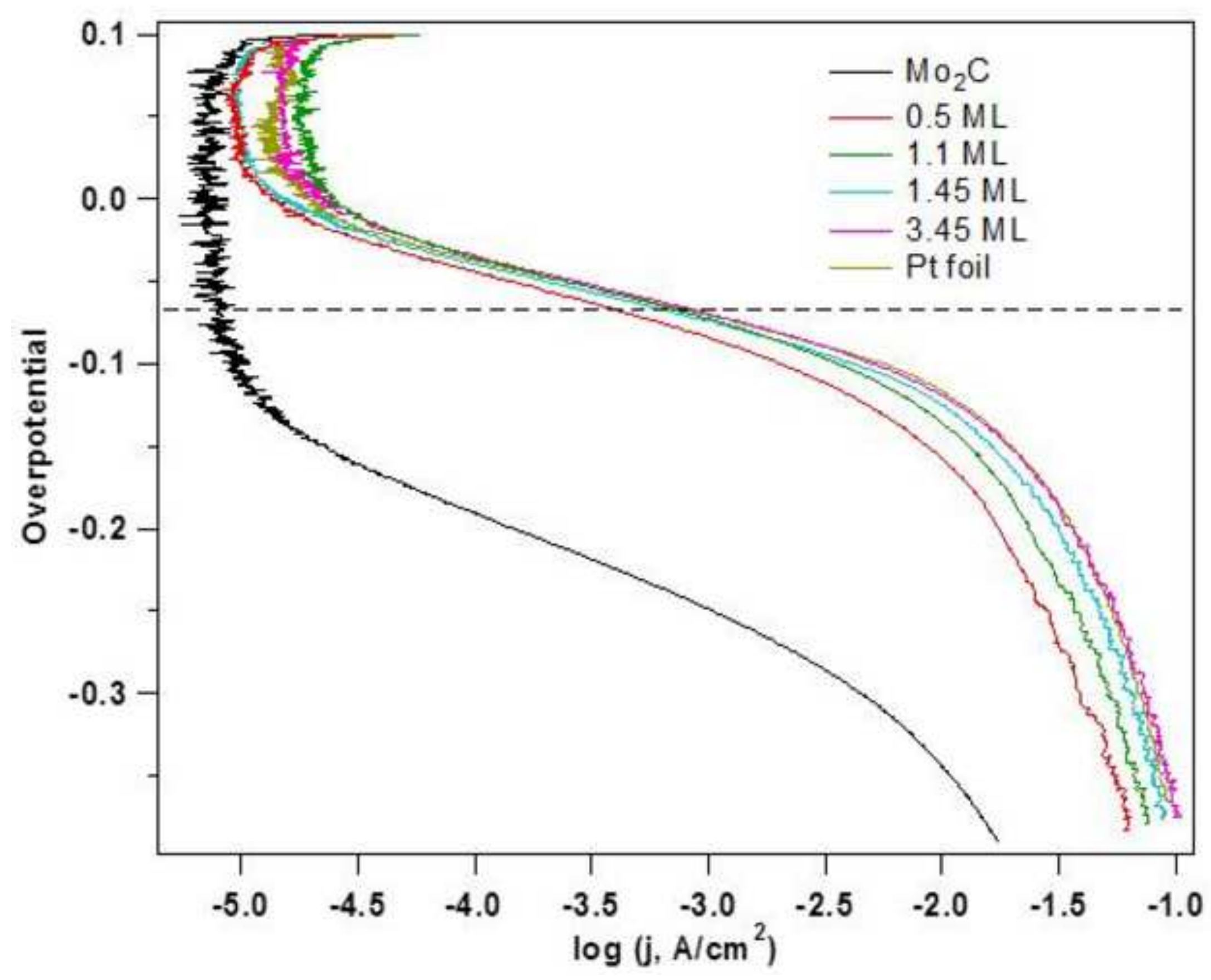




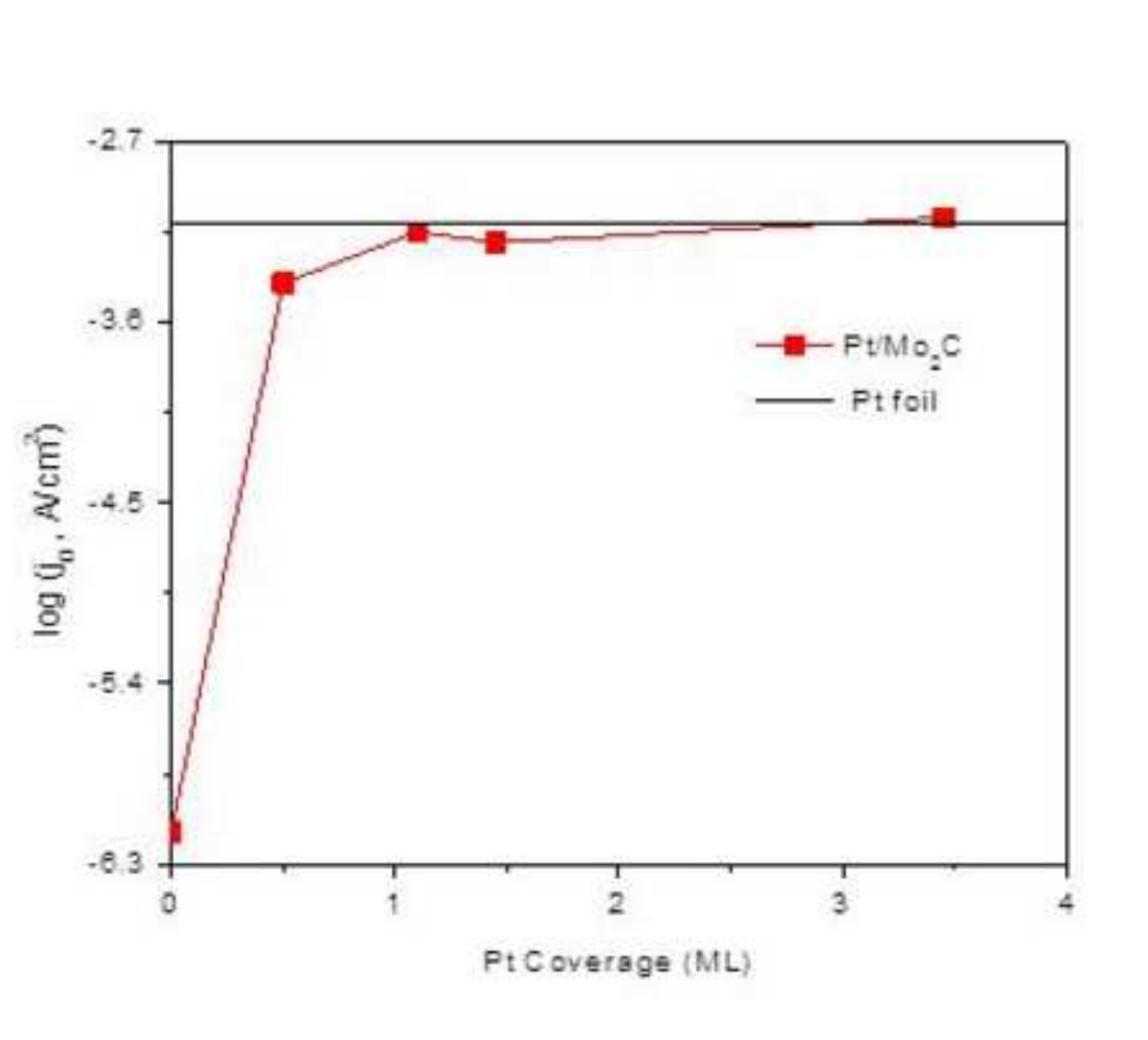

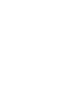
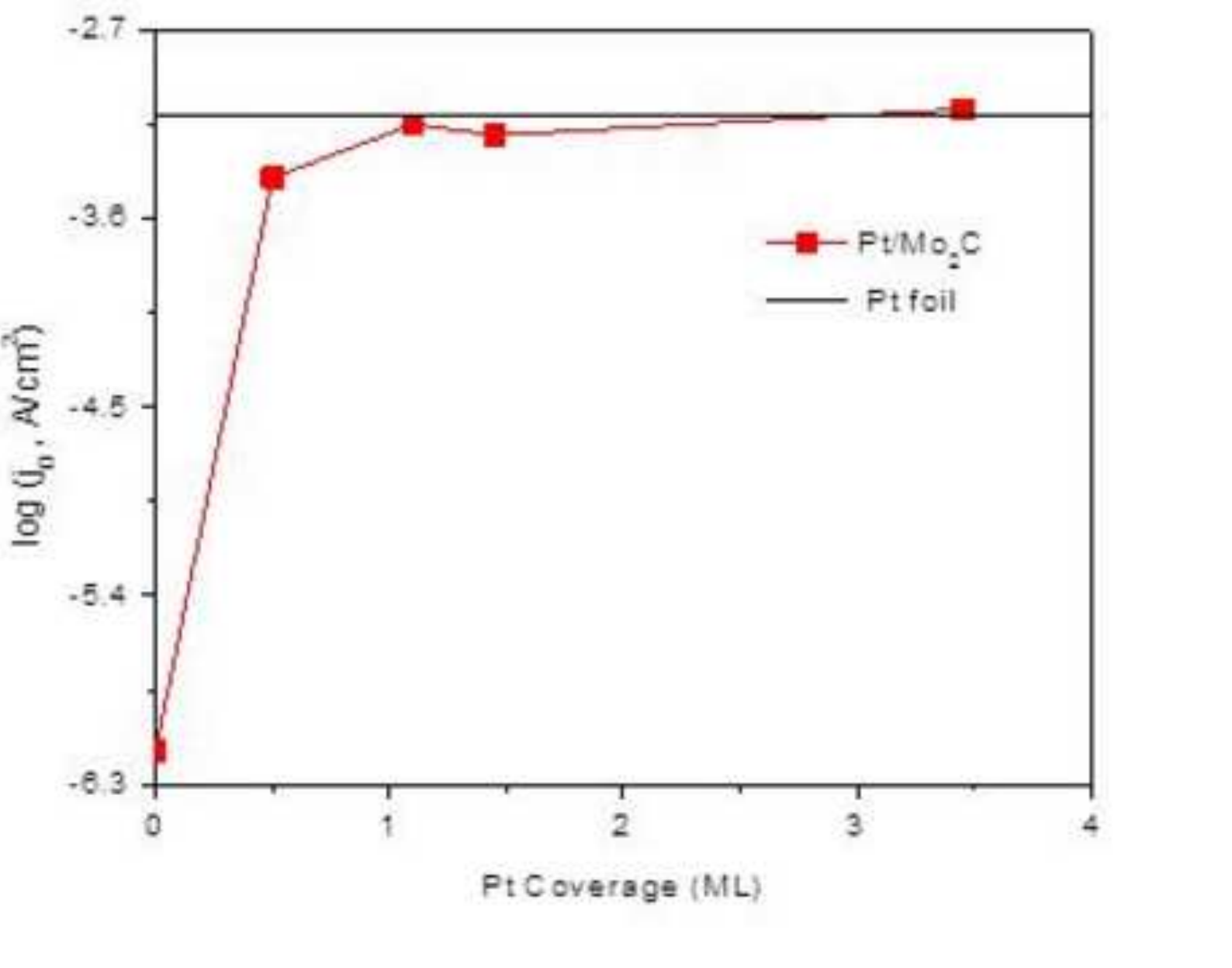

PtC overage (MIL) 


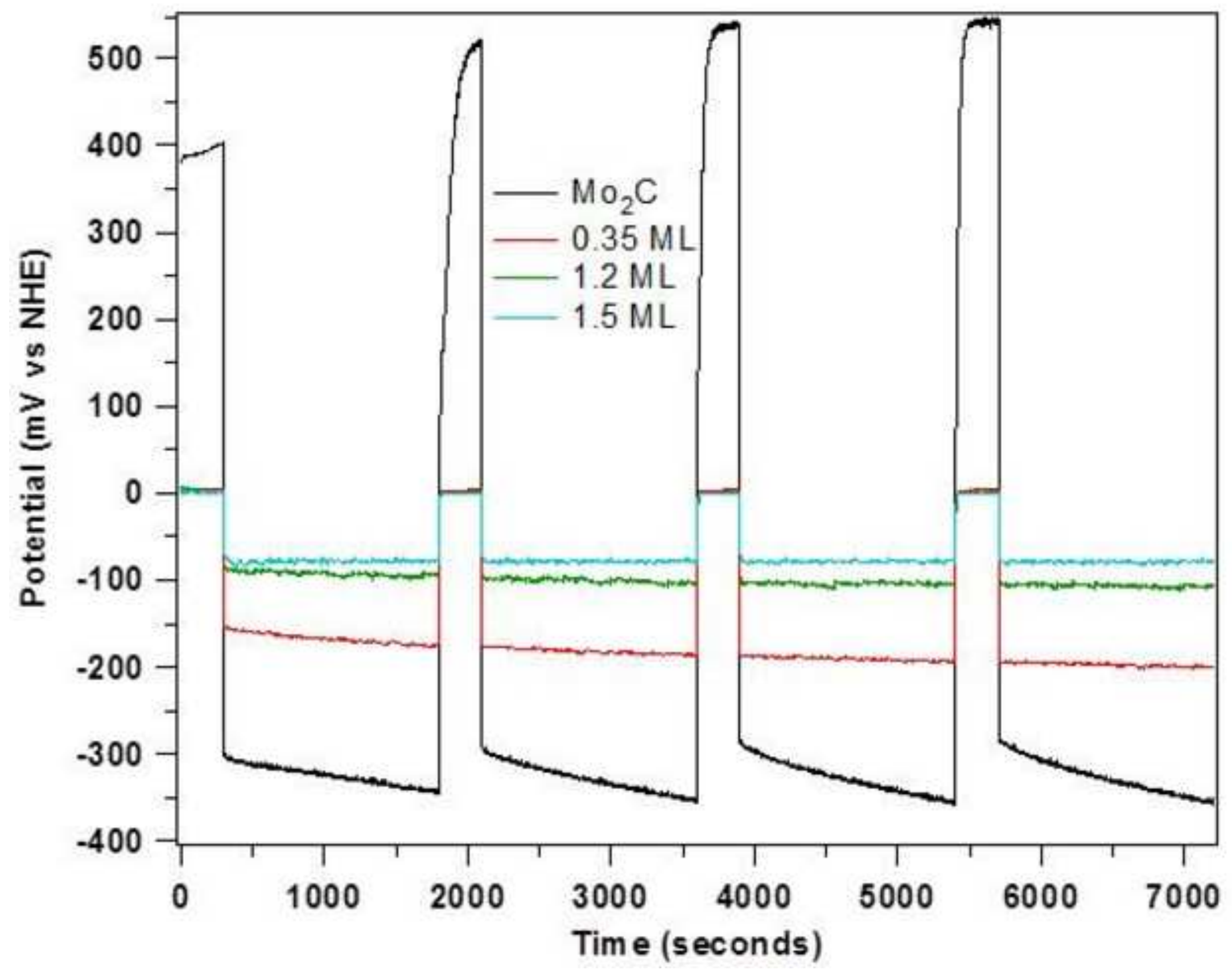




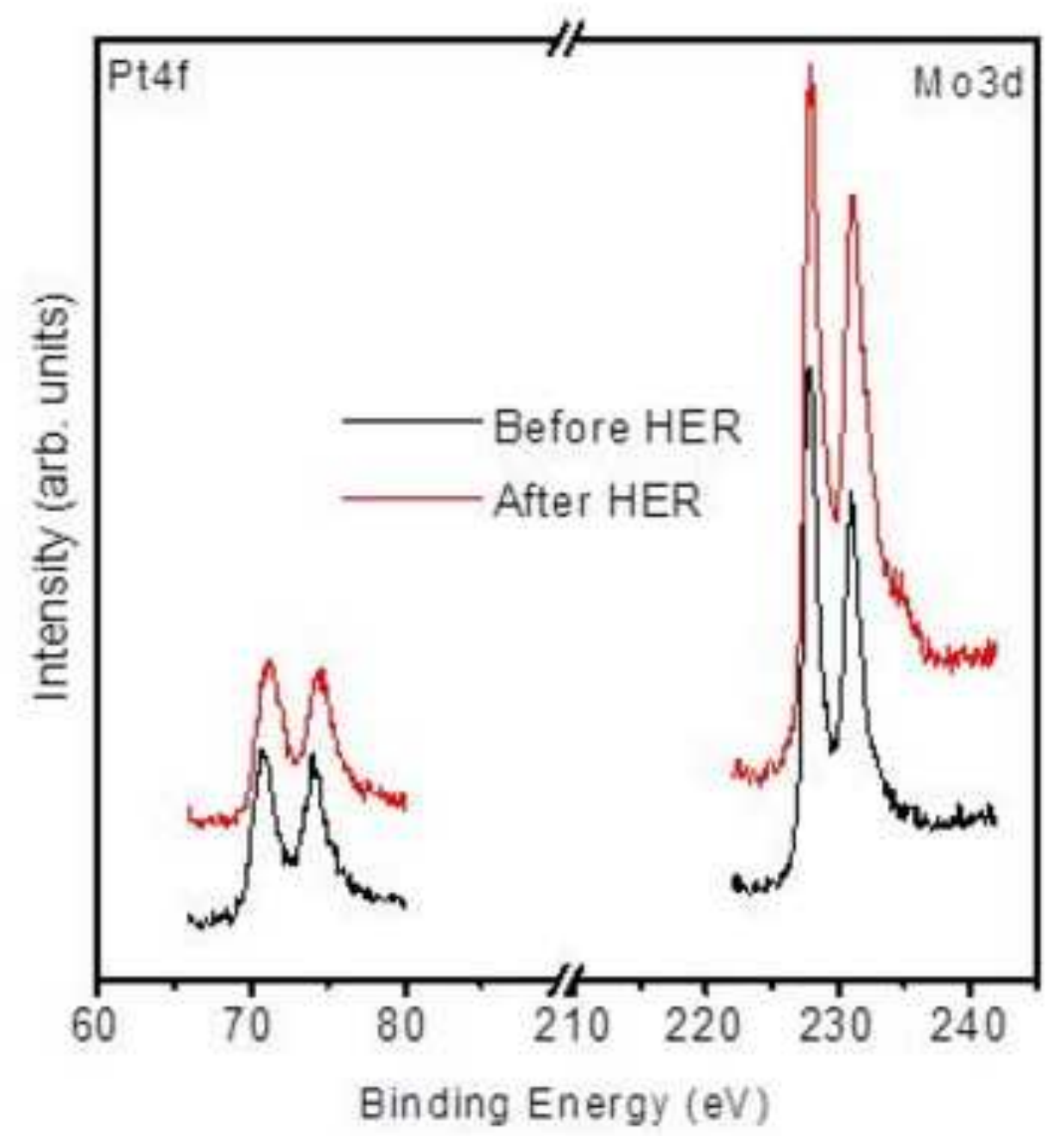




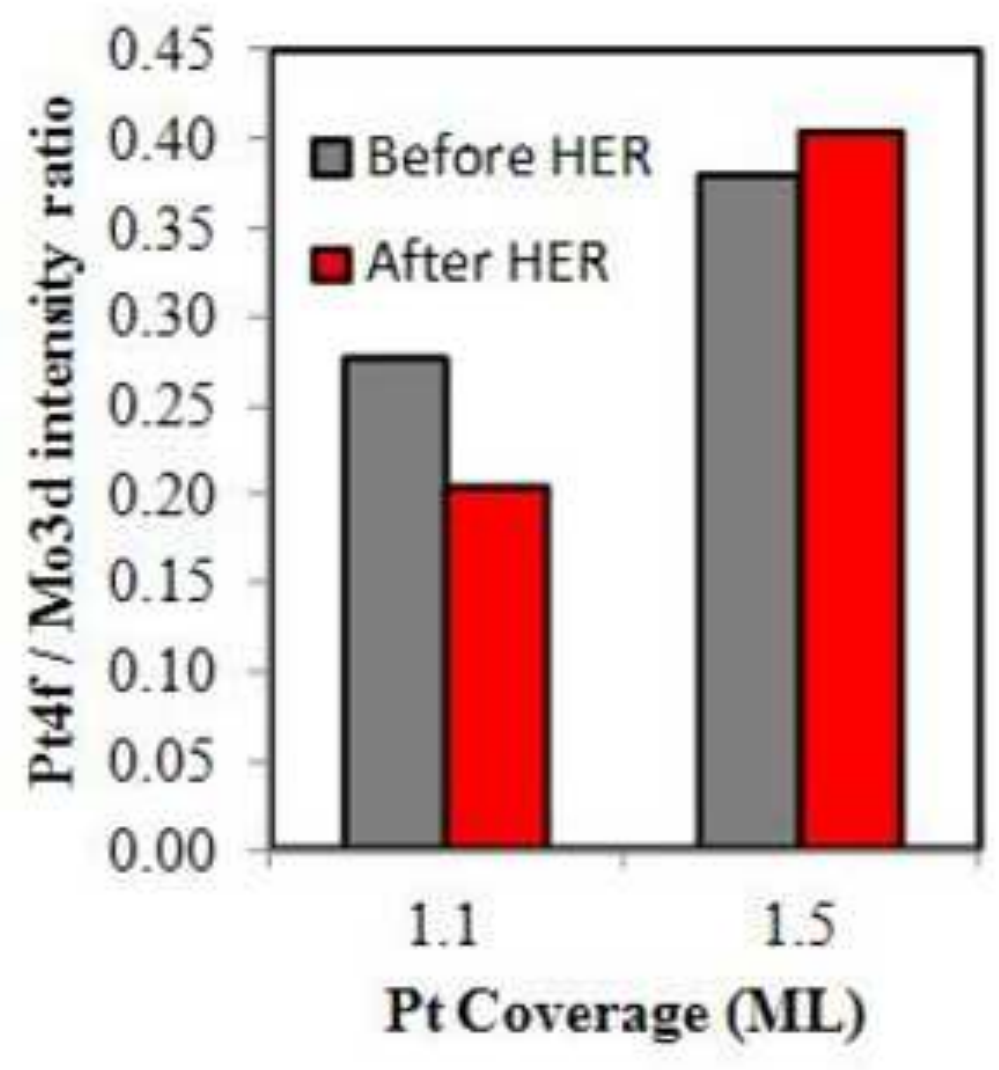


Figure $8 b$

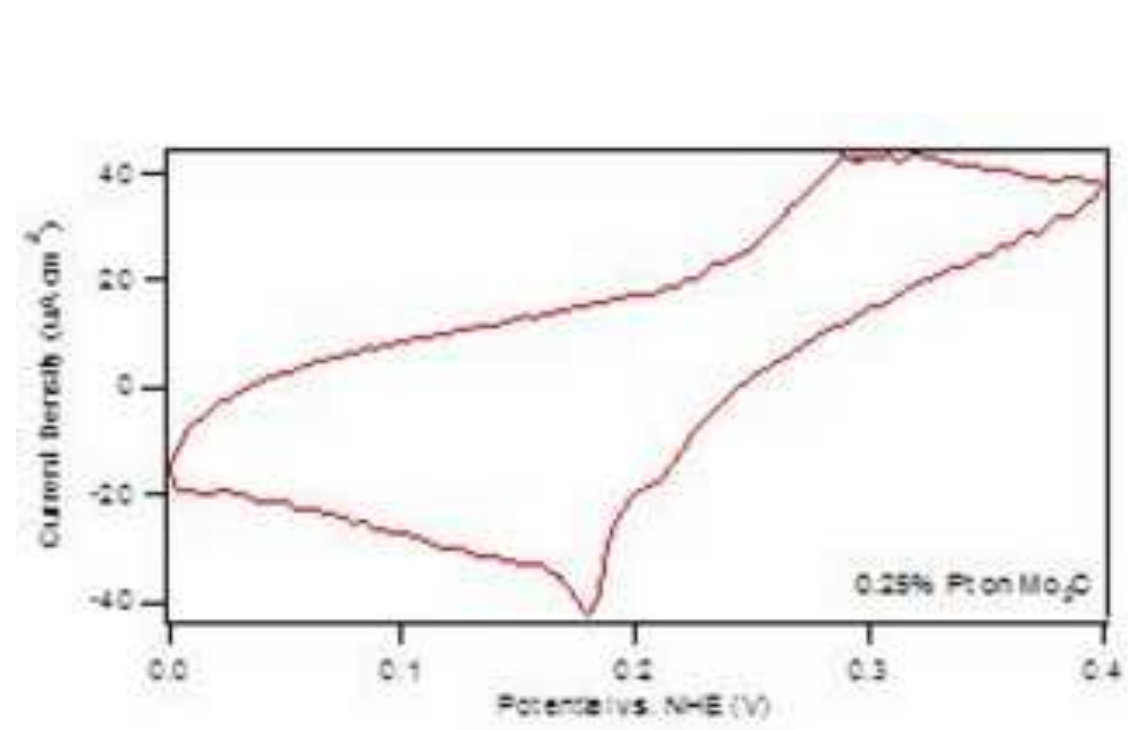

\section{Figure 8}




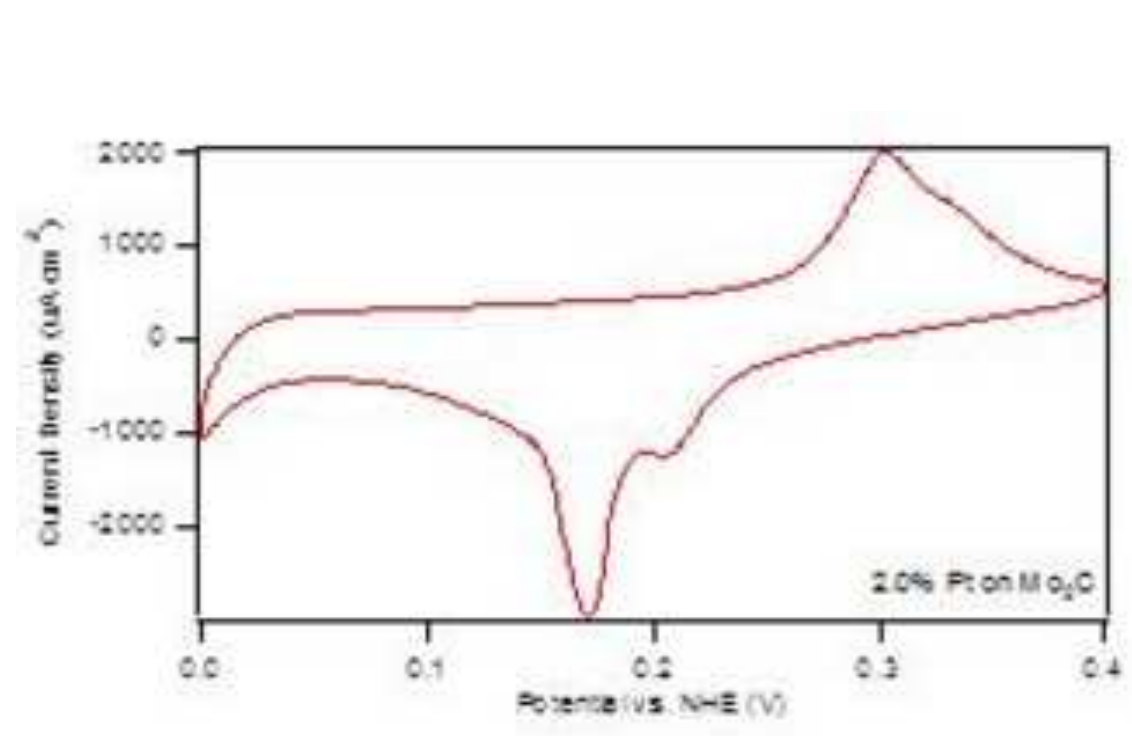

\section{Figure 8}




\section{Fyures \\ Figure 8d}

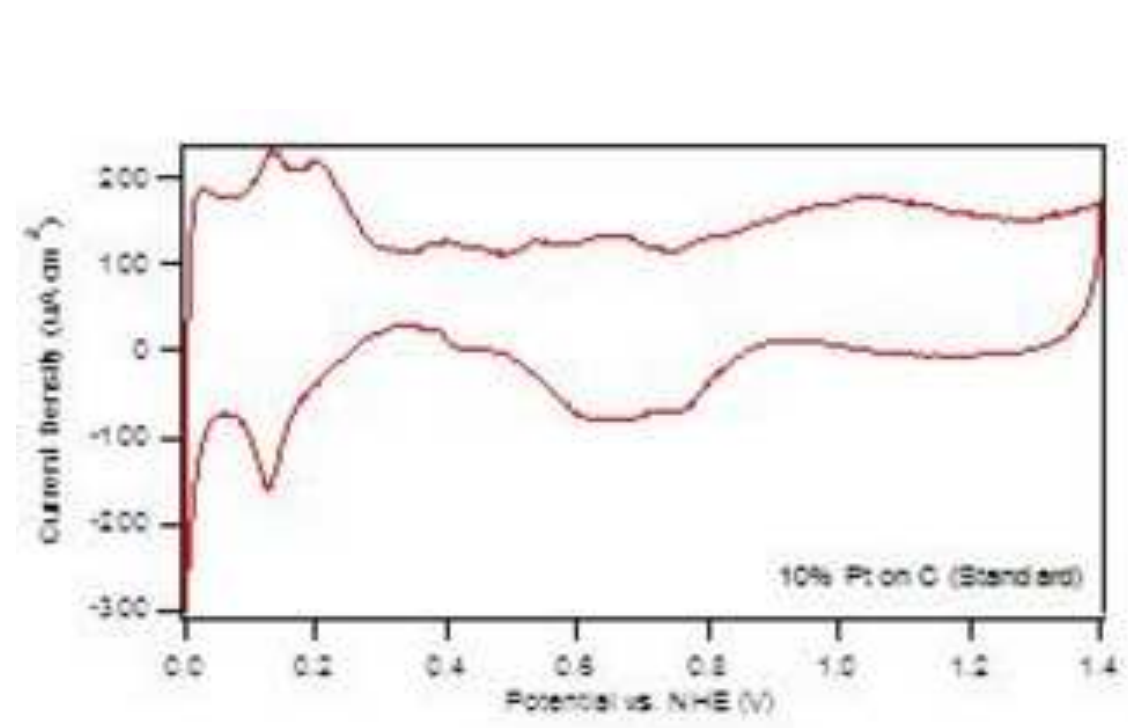




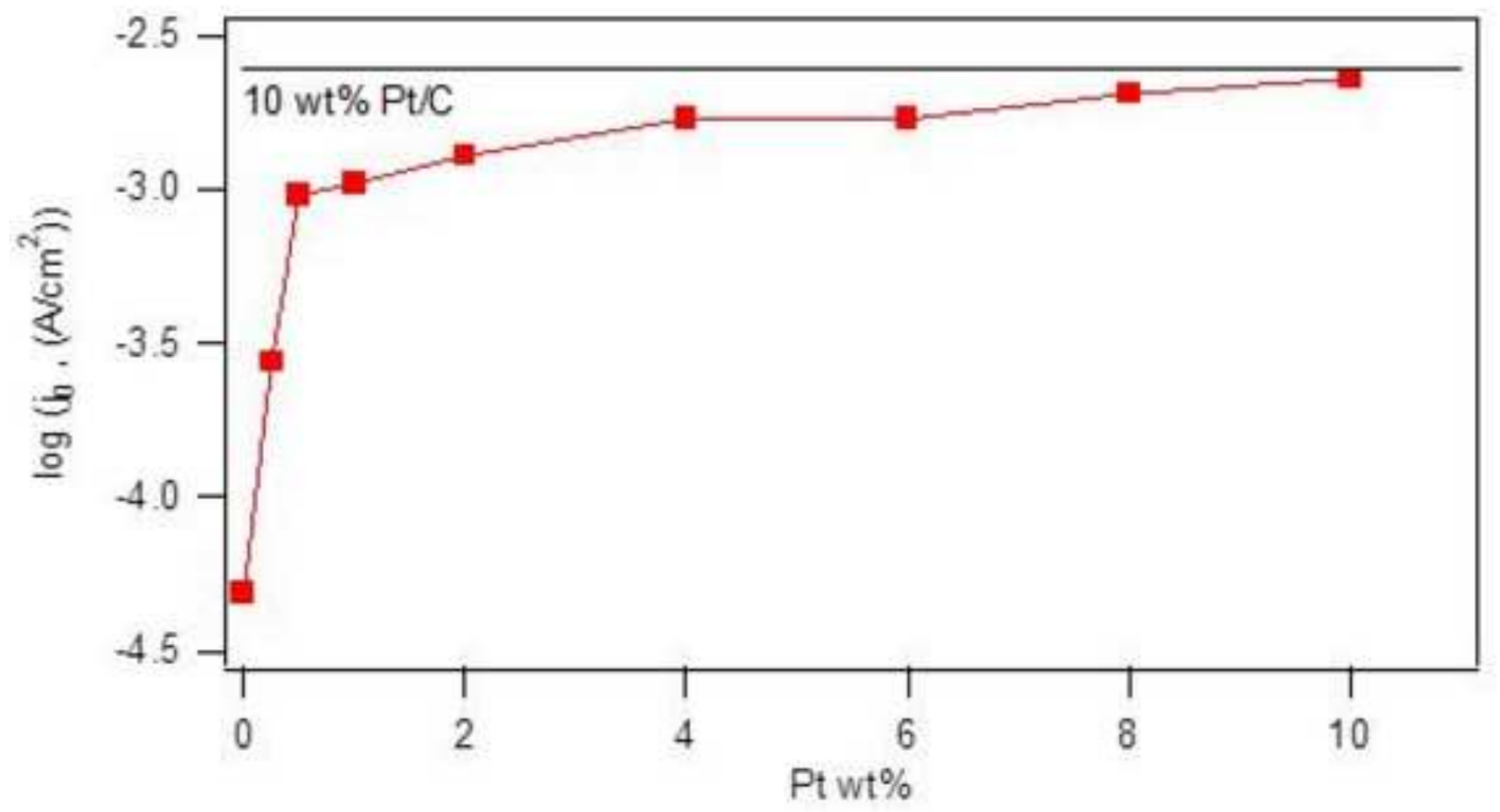

